\title{
Cyanobacteria Composition and Impact of Seasonality on their In Situ Nitrogen Fixation Rate in a Mangrove Ecosystem Adjacent to Zanzibar Town
}

\author{
J.J. Kyaruzi ${ }^{1,2}$, M.S. Kyewalyanga ${ }^{1}$ and M.H.S. Muruke ${ }^{2}$ \\ ${ }^{1}$ Institute of Marine Sciences, University of Dar es Salaam, P. O. Box 668, Zanzibar, Tanzania; ${ }^{2}$ Department of \\ Botany, Applied Microbiology Unit, University of Dar es Salaam, P.O. Box 35060, Dar es Salaam, Tanzania
}

\begin{abstract}
Key words: cyanobacteria composition, nitrogen fixation, seasonality, mangrove ecosystem
Abstract-To investigate the input of combined nitrogen by cyanobacteria in mangrove ecosystems and the seasonal fluctuation of this biological process, in situ nitrogen fixation activity was measured in day and night experiments carried out at Maruhubi mangrove ecosystem adjacent to Zanzibar town. Sampling was done for 12 months at two stations: Station I covering sandy sediments and Station II muddy sediments. Associated cyanobacteria genera were identified and environmental variables were measured throughout the study period. A total of 10 genera of cyanobacteria were encountered, two of which were the heterocystous cyanobacteria genera Anabaena and Rivularia and eight the non-heterocystous genera Aphanocapsa, Merismopedia, Lyngbya, Microcoleus, Oscillatoria, Phormidium, Schizothrix and Spirulina. At both stations $\mathrm{N}_{2}$ fixation during the night was significantly higher $(\mathrm{P} \leq 0.05)$ than during the day. The average $\mathrm{N}_{2}$-fixation rates at stations I and II were 1.64 and $1.34 \mathrm{nmole} \mathrm{N}_{2} / \mathrm{hr} / \mathrm{m}^{2}$ respectively, with no significant differences $(\mathrm{P} \leq 0.05)$ observed between seasons at both stations, or between stations in the rainy season. There was no significant correlation $(P \leq 0.05)$ between nitrogen fixation and physical-chemical variables, except sediment temperature, which showed a significant direct relationship with $\mathrm{N}_{2}$ fixation rate at Station I only. The results suggest that in the investigated ecosystem cyanobacterial diversity and nitrogen fixation are high; and generally seasonal changes do not have a significant influence on nitrogen fixation. It is therefore concluded that cyanobacterial diversity and nitrogen fixation process may contribute in the promotion of primary productivity in the mangrove ecosystem adjacent to Zanzibar town.
\end{abstract}

\section{INTRODUCTION}

Mangrove ecosystem sediments are frequently characterised by dense populations of cyanobacteria, many of which are known to fix atmospheric nitrogen (Toledo et al., 1995). Nitrogen fixation is one of the important sources of combined nitrogen in mangrove ecosystems (Hicks \& Sylvester, 1985). In nature, the process of nitrogen fixation is important in counterbalancing losses of combined nitrogen from the environment by dinitrification (Villbrandt et al., 1991). The reduction of atmospheric nitrogen is catalysed by the enzyme-complex nitrogenase that occurs in prokaryotic organisms such as cyanobacteria (Stal, 2000).

Nitrogen fixation in mangroves, first described by Zuberer \& Silver (1974, 1978), is well documented in several mangrove communities (Potts, 1984). For example Potts (1979) measured nitrogen fixation on sediment surfaces of Sinai mangrove forests, and found a mean rate of $8.6 \mu \mathrm{g}$ $\mathrm{N} / \mathrm{m}^{2} / \mathrm{d}$. Boto \& Robertson (1991) reported a mean rate of $1.45 \mu \mathrm{g} \mathrm{N} / \mathrm{m}^{2} / \mathrm{d}$ in mangrove ecosystem 
sediments of Hinchinbrook, Australia. Other components such as bark, leaf litter, $\log$ s, pneumatophores and prop roots have shown nitrogen-fixing abilities related to the abundance of epiphytic cyanobacteria (Potts, 1979). In Sinai, Potts (1979) found high rates of nitrogen fixation on pneumatophores covered with cyanobacteria. In a coastal lagoon in Kenya, Woitchek et al. (1997) found that biological nitrogen fixation account for between 13 and $21 \%$ of the maximum nitrogen mobilised from decaying mangrove leaves. In the north of Lapaz, Baja California Sur, Mexico, Toledo et al. (1995) observed seasonal fluctuations in in situ nitrogen fixation by cyanobacteria growing on surrounding sediments on the mangrove pneumatophores. According to their findings, nitrogen fixation was low during winter, increased in early summer and reached a peak in mid summer. In addition, light and temperature were found to be the primary environmental factors governing nitrogen fixation on pneumatophores. However, more information is needed on the seasonal effects of nitrogen fixation in mangrove ecosystems of Zanzibar Island.

Mangroves are among the most productive ecosystems in marine and estuarine environments (Robertson, 1986; Alongi et al., 1992). According to Shunula \& Whittick (1996), mangrove density and distribution in Tanzania is influenced by several factors, including anthropogenic activities and nutrient availability. Due to rapid increase of population and economic activities along the coast, some of the Tanzanian mangrove ecosystems, especially those near urban centres, have been under threat from anthropogenic disturbances (Semesi, 1991; Semesi et al., 1999). So far, little is known about nitrogen fixation in Tanzanian mangroves.

The specific objectives of this study were to (i) assess the impact of seasonality on in situ nitrogen fixation rate, and (ii) identify the cyanobacterial genera from the cyanobacterial mats associated with mangrove ecosystem sediments. The study was carried out in a mangrove ecosystem adjacent to Zanzibar Town.

\section{MATERIALS AND METHODS}

\section{Area of investigation}

Maruhubi mangrove ecosystem was selected as the study site. This area is adjacent to Zanzibar town, on the west coast of the Unguja Island (Fig.1). The ecosystem is subject to high human impact and disturbances. Cyanobacterial mats cover the sediments surrounding the mangrove communities of this area.

\section{Sampling}

Sampling was done at two stations where the cyanobacterial mats were covering sandy sediments (Station I) and muddy sediments (Station II) respectively. Station I is situated west of Funguni creek outlet, while Station II is situated in the middle of the same creek (Fig. 1). Preliminary sampling was carried out during January-March 1999, when sampling stations and research methods were also established. Regular sampling at the study site commenced in April 1999 and continued until March 2000. Sampling was always done twice a month, during the neap and/or spring low tides.

\section{Cyanobacteria identification}

Biofilms or microbial mats with sediments were taken from cores collected as described below, for identification of cyanobacteria in the laboratory using light microscopy (BHT system Olympus, Japan). Cyanobacteria were identified to genus level as described by Rippka et al. (1979).

\section{In situ measurements of nitrogen fixation activity}

In the field, nitrogen fixation rates in the exposed benthic sediments associated with cyanobacteria were evaluated during the day and night at low tide twice a month, using the acetylene reduction assay (ARA) in plexiglass cores by the Bell-Jar Method described in Stal (1988).

At each sampling station, 3-4 plexiglass cores (49.4 mm diameter, 400 or $600 \mathrm{ml}$ total volume) with two rubber stoppers for sealing top-cover and syringe injection port $(1 \mathrm{~cm}$ diameter, hole just 


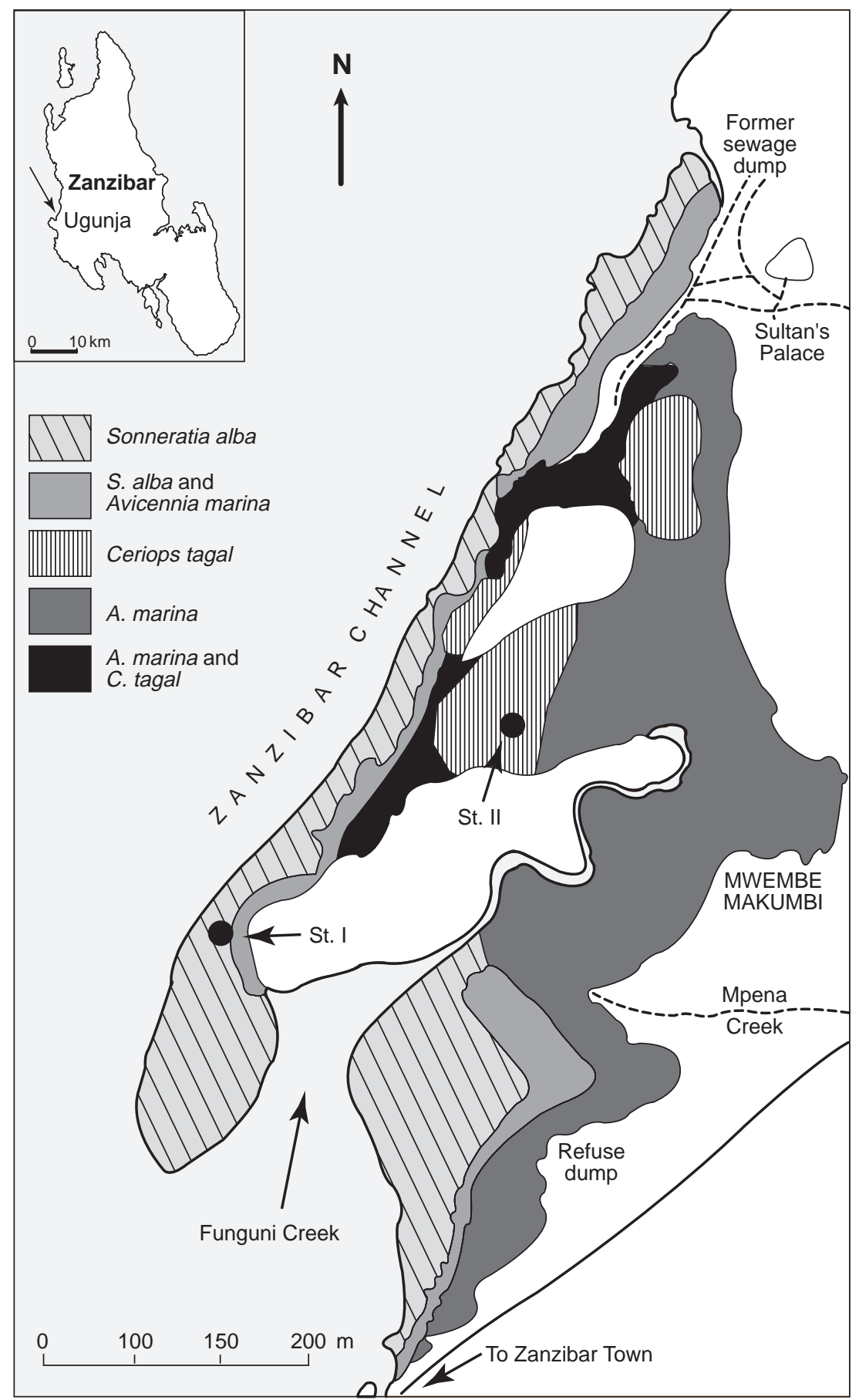

Fig. 1. Maruhubi mangrove area in Unguja Island, showing sampling stations. Inset: Study site is indicated by the arrow. 
below the top-seal, for gas injection and withdraw) were used. One core was used as a control to see whether ethylene gas was produced from the sediments without the addition of acetylene gas. The cores were pressed into the sediment randomly over an area of $1 \mathrm{~m}^{2}$ until about $1 / 3$ of the core length remained above the sediment surface. $10 \%$ of the air phase was withdrawn from the core using a syringe, and replaced by the same volume of acetylene gas generated from calcium carbide as described by Burris (1974). After two hours incubation, the gas phase was withdrawn using a syringe and transferred to 7,5 , or $4 \mathrm{ml}$ preevacuated vacutainers (Becton-Dickinson). In the field the vacutainers were wrapped in plastic bags and kept on ice.

In the laboratory, samples were kept at room temperature in darkness for later gas chromatography. One millilitre $(1 \mathrm{ml})$ gas samples were taken from each vacutainer and analysed for ethylene content using a SHIMADZU GC-8AIF (Japan) gas chromatograph equipped with a flame ionisation detector and coupled to a computer running the CSW-Chromatography Station for Windows 1.7 software. The $3-\mathrm{m}$ column was packed with Porapak R (50-80 mesh), and held at $50{ }^{\circ} \mathrm{C}$ during analysis. The injector and detector temperatures were 150 and $120^{\circ} \mathrm{C}$ respectively. Nitrogen served as a carrier gas at a pressure of 70 $\mathrm{kPa}$. The pressure of hydrogen and air were 60 and $50 \mathrm{kPa}$, respectively. Pure ethylene $(100 \mathrm{ppm}$, AGA, Sweden) was used as standard gas. Peak areas were used to calculate ethylene content as described by Jonsson (1988). The values were divided by 2 hrs of incubation as well as core area, and expressed as $\mathrm{nmol}_{2} \mathrm{H}_{4}$ produced per area per hour. For calculations of fixed nitrogen, ethylene values were divided by the theoretical conversion factor of four (Jonsson, 1988).

\section{Assessment of environmental variables and nitrate- $\mathrm{N}$ concentration}

Environmental variables were measured and recorded at each sampling station during the daylight at low tide before the incubations. Light intensity (in $\mu \mathrm{mol}$ photons $/ \mathrm{m}^{2} / \mathrm{s}$ ) was measured using a light meter (Hansatech QTP1 9521). Air and sediment temperatures (in ${ }^{\circ} \mathrm{C}$ ) were also recorded. Rainfall data were taken from the meteorology department of Zanzibar, $\mathrm{pH}$ was determined using a pH meter $(\Omega$, Metrohm, Switzerland) and salinity was measured in the field using a handheld refractometer (ATAGOS, Japan).

Nitrate-N from sediments pore water samples was determined as described in Parsons et al. (1989). For each station, field sampling of sediments involved five parallel transects, $10 \mathrm{~m}$ apart. The transects at each station ran from the west bank of Funguni creek to the interior of the mangrove forest. For each sampling transect, six sampling points were established, $10 \mathrm{~m}$ from one another. At each sampling point along the transect, a core of $79.4 \mathrm{~mm}$ diameter was used to collect sediments $5 \mathrm{~cm}$ deep. Sediments were kept on ice and transferred to the laboratory in plastic bags. In the laboratory sediment samples were centrifuged at $3000 \mathrm{rpm} x \mathrm{~g}$ for 10 minutes. Pore water of about $100 \mathrm{ml}$ was extracted from the sediments at each station. The pore water was filtered through a $0.45 \mu \mathrm{m}$ filter. If not analysed immediately, the prepared samples for nitrate determination were kept frozen at $-20{ }^{\circ} \mathrm{C}$ until analysis (Johnstone \& Preston, 1993).

\section{Statistical analysis}

All in situ incubation experiments and sampling were performed in triplicate. For statistical analysis the GraphPad Software package (GraphPad Software, USA) was used. Differences in nitrogen fixation rates between sampling seasons, day and night as well as stations were determined by Wilcoxon's paired sample test. Spearman Rank Correlations $\left(r_{s}\right)$ were performed to test for statistical relationships between nitrogen fixation rates and environmental variables for both study stations.

\section{RESULTS}

\section{Cyanobacterial composition}

A total of 10 genera of cyanobacteria were encountered; 8 non-heterocystous and 2 heterocystous. The former also had significantly higher frequency at both stations $(\mathrm{P}<0.05$, Wilcoxon's paired sample test). There was no 
significant difference in the diversity of the two types of cyanobacterial groups between stations. The eight non-heterocystous genera found were Aphanocapsa, Merismopedia, Lyngbya, Microcoleus, Oscillatoria, Phormidium, Schizothrix and Spirulina and the two heterocystous genera were Anabaena and Rivularia. In general microbial mats in sandy as well as muddy sediments were dominated (up to 90\%) by one or two cyanobacterial genera. Description of the cyanobacterial species is based on morphology, the months in which they were observed and other field characteristic features noted.

\section{Non-heterocystous cyanobacteria}

\section{Order Chroococcales, Family Microcystaceae}

The following genera were found:

\section{Aphanocapsa}

One species was identified.

Aphanocapsa sp. formed blue-green films on sandy and muddy sediments and was also found on leaf litter. However, it was uncommon, found only during the months of September and December 1999. Its cells were spherical without sheath, and about 4.4-6.0 $\mu \mathrm{m}$ in diameter.

\section{Merismopedia}

One species was identified.

Merismopedia sp. was observed to form bluegreen films on sandy sediments and it was uncommon, found only during the months of April, August and November 1999. Cells were about 3.0$\mu \mathrm{m}$ wide and $6.5 \mu \mathrm{m}$ long, aggregating to form cubical or rectangular colonies with no sheath.

\section{Order Oscillatoriales, Family Oscillatoriaceae}

The following genera were found:

\section{Lyngbya}

Two species were identified.

Lyngbya sp. 1 was found to form blue-green films on muddy and sandy sediments. It was found throughout the study duration. Its cells were 11.9$14.5 \mu \mathrm{m}$ wide and $2.5-4.2 \mu \mathrm{m}$ long, with a firm sheath around the filaments.

Lyngbya sp. 2 formed blue-green hair-like filaments on muddy and sandy sediments. However, it was uncommon, found only in January and March 2000. Its cells were about 14.8-17.5 $\mu \mathrm{m}$ wide and 1.8-2.7 $\mu \mathrm{m}$ long with a firm sheath, and the terminal cells were round.

\section{Microcoleus}

Two species were identified.

Microcoleus sp. 1 formed dark green mats. It was common in both sandy and muddy sediments throughout the study duration. Cell widths ranged from $6.5-9.5 \mu \mathrm{m}$ and length from $13-15.8 \mu \mathrm{m}$. Filaments joined together to form a cluster of parallel filaments without a sheath. Terminal cells were conical in shape.

Microcoleus sp. 2 formed dark green mats on sandy and muddy sediments. It was uncommon, found during April-July 1999 and March 2000. Cells, measuring 2-4.5 $\mu \mathrm{m}$ in width and 6.5-7.6 $\mu \mathrm{m}$ in length, joined together to form a cluster of parallel filaments within a common sheath. Terminal cells were conical in shape.

\section{Oscillatoria}

Seven species were identified.

Oscillatoria sp. 1 formed brownish-green films on muddy and sandy sediments. It was commonly found throughout the whole sampling period except in April 1999. Cells were 14.4-18 $\mu \mathrm{m}$ wide and $2.6-5.7 \mu \mathrm{m}$ long and slightly constricted at cross walls.

Oscillatoria sp. 2 formed brown or olive-green mats on muddy and sandy sediments and was uncommon, found only in June and July 1999. Its cells were 20-25 $\mu \mathrm{m}$ wide and $2.5-4 \mu \mathrm{m}$ long. Terminal cells were round and not constricted at cross walls.

Oscillatoria sp. 3 formed brownish-green mats on muddy and sandy sediments. It was common, found throughout the sampling period. Its cells were 9.4-13.0 $\mu \mathrm{m}$ wide and 2.4-3.0 $\mu \mathrm{m}$ long with round terminal cells.

Oscillatoria sp. 4 formed dark-green films on muddy and sandy sediments. It was common and found throughout the study duration. Its cells were $10-13.4 \mu \mathrm{m}$ wide and 3.2-6.2 $\mu \mathrm{m}$ long. Terminal cells were round.

Oscillatoria sp. 5 formed olive-green films on muddy and sandy sediments. It was common, 
found throughout the study duration. Its cells were 7-10 $\mu \mathrm{m}$ wide and $2.5-6.1 \mu \mathrm{m}$ long. Terminal cells were not round.

Oscillatoria sp. 6 formed green films on sandy sediments. It was uncommon, found only during August and September 1999. Its cells were 6.1$8.0 \mu \mathrm{m}$ wide and 6-9.5 $\mu \mathrm{m}$ long and slightly constricted at cross walls.

Oscillatoria sp. 7 formed blue-green films on muddy and sandy sediments. It was uncommon, found only during February and March 2000. Cells were $3.2-\mu \mathrm{m}$ wide and $6.5 \mu \mathrm{m}$ long and arranged close together in cubical or rectangular colonies with no sheath.

\section{Phormidium}

Two species were identified.

Phormidium sp. 1 formed green films on muddy and sandy sediments. It was common, found throughout the study duration. Its cells were $1.7-2.1 \mu \mathrm{m}$ wide and $1.5-5.0 \mu \mathrm{m}$ long, with rounded terminal cells in the filament.

Phormidium sp. 2 formed green films on muddy and sandy sediments. It was common, found throughout the study duration. Its cells were 2.7-3.4 $\mu \mathrm{m}$ wide and up to $6.5 \mu \mathrm{m}$ long, with rounded terminal cells of the filaments.

\section{Schizothrix}

One species was identified.

Schizothrix sp. formed blue-green mats on muddy and sandy sediments. It was commonly found during October-December 1999. Cells were 6.5-10.5 $\mu \mathrm{m}$ wide and 3.2-10.5 $\mu \mathrm{m}$ long, forming short filaments without a surrounding sheath. Terminal cells of the filaments were cylindrical or rounded.

\section{Spirulina}

Three species were identified.

Spirulina sp. 1 formed brown or green films on muddy and sandy sediments. It was common throughout the sampling period. Filaments were $1.2-1.6 \mu \mathrm{m}$ wide, forming loosely packed spirals 2.5-3.4 $\mu \mathrm{m}$ wide and 2.5-3.3 $\mu \mathrm{m}$ apart.

Spirulina sp. 2 formed green films on muddy and sandy sediments. It was commonly found throughout the study duration. Its filaments were 1.2$1.6 \mu \mathrm{m}$ wide, forming moderately packed spirals.
Spirulina sp. 3 formed green films on muddy and sandy sediments. It was common, found throughout the whole sampling period. Its filaments were $0.5-1.0 \mu \mathrm{m}$ wide, forming loosely packed spirals, $1.2-1.6 \mu \mathrm{m}$ wide and $1.5-2.4 \mu \mathrm{m}$ apart.

\section{Heterocystous cyanobacteria}

\section{Order Nostocales, Family Nostocaceae}

The following genera were found:

\section{Anabaena}

Two species were identified.

Anabaena sp. 1 formed olive/green films on muddy and sandy sediments. It was common and found throughout the sampling period. Its filaments consisted of spherical cells, 5.0-6.0 $\mu \mathrm{m}$ wide and 4.9-6.0 $\mu \mathrm{m}$ long. Heterocysts were 5.0-6.1 $\mu \mathrm{m}$ wide and 5.0-8.7 $\mu \mathrm{m}$ long.

Anabaena sp. 2 formed blue-green films on muddy sediments. It was found throughout the sampling period. Its cells were spherical, 6.0-6.5 $\mu \mathrm{m}$ wide, 3.9-7.0 $\mu \mathrm{m}$ long, and the heterocysts 6.5$7.3 \mu \mathrm{m}$ wide and 6.5-9.7 $\mu \mathrm{m}$ long. The terminal cells were rounded.

\section{Rivularia}

One species was identified.

Rivularia sp. formed brownish films on muddy sediments. It was uncommon, found only in January and February 2000. The diameters of the heterocysts were about $8.7 \mu \mathrm{m}$.

\section{Nitrogen fixation}

The nitrogen fixation rates recorded from day and night in situ measurements on sandy (Station I) and muddy (Station II) sediments are presented in Fig. 2. The average $\mathrm{N}_{2}$-fixation rate at station I was $1.64 \mathrm{nmole} \mathrm{N}_{2} / \mathrm{hr} / \mathrm{m}^{2}$, while at station II, it was 1.34 nmole $\mathrm{N}_{2} / \mathrm{hr} / \mathrm{m}^{2}$.

At station I, the nitrogen fixation rate during the night was significantly higher (Wilcoxon's paired sample test: $\mathrm{W}=-236, \mathrm{n}=24$ and $\mathrm{P}=0.001$ ) than during the day. Similarly at station II, the significantly higher $(\mathrm{W}=-196, \mathrm{n}=24$ and $\mathrm{P}=$ 0.005 ) nitrogen fixation rate was observed during the night than during the day. The difference in nitrogen fixation rate between dry and rainy 


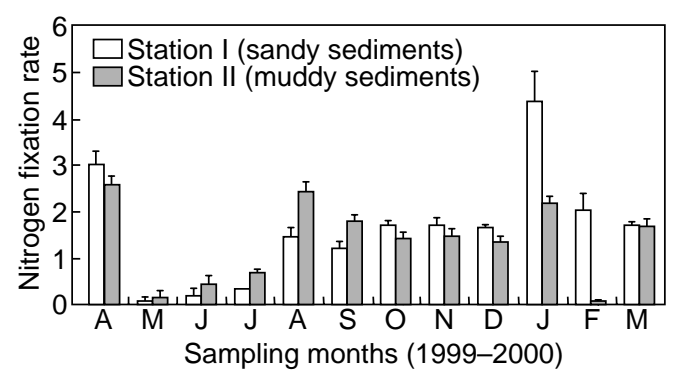

Fig. 2. Seasonal variations of in situ nitrogen fixation at study stations of Maruhubi mangrove ecosystem ( $n=12$; small bars represent the standard deviation). $\mathrm{N}_{2}$ fixation rate is presented in nmole $N_{2} / h r / m^{2}$. seasons was not significant at either station (Wilcoxon's paired sample test).

There was no significant $(\mathrm{P}<0.05)$ difference in nitrogen fixation rate between stations at day or night times (Wilcoxon's paired sample test). Similarly, during the rainy season there was no significant difference between stations $(\mathrm{W}=16$, $\mathrm{n}=24$ and $\mathrm{P}=0.83$ ). However during the dry season the nitrogen fixation rate at station I was significantly higher $(\mathrm{W}=164, \mathrm{n}=24$ and $\mathrm{P}=$ $0.0199)$ than that observed at station II.

The results of physical-chemical environmental variables recorded from sandy and muddy sediments are presented in Tables 1 and 2 .

Table 1. Seasonal variation of physical environmental variables measured at sampling stations at Maruhubi mangrove ecosystem (mean values \pm std error, except rainfall, $n=8$ )

\begin{tabular}{|c|c|c|c|c|c|c|c|c|}
\hline \multirow[b]{2}{*}{ Month } & \multicolumn{2}{|c|}{ Sediment temp $\left({ }^{\circ} \mathrm{C}\right)$} & \multicolumn{3}{|c|}{ Air temperature $\left({ }^{\circ} \mathrm{C}\right)$} & \multicolumn{2}{|c|}{$\begin{array}{l}\text { Light intensity } \\
\left(\mu \mathrm{mol} \text { photons } / \mathrm{m}^{2} / \mathrm{s}\right)\end{array}$} & \multirow{2}{*}{$\begin{array}{l}\text { Rainfall } \\
\text { (mm) } \\
\text { St. I \& } \\
\text { St. II }\end{array}$} \\
\hline & St. I & St. II & St. I & & St. II & St. I & St. II & \\
\hline Apr & $27.3 \pm 0.7$ & $27.0 \pm 0.7$ & $27.7 \pm 1.1$ & 28.4 & \pm 1.0 & $431.6 \pm 109.4$ & $335.9 \pm 43.2$ & 316 \\
\hline May & $27.9 \pm 0.7$ & $28.2 \pm 1.0$ & $29.7 \pm 1.1$ & 29.6 & \pm 1.2 & $274.0 \pm 100.5$ & $223.8 \pm 133.3$ & 186.2 \\
\hline Jun & $27.5 \pm 0.3$ & $28.5 \pm 0.3$ & $30.6 \pm 0.5$ & 30.2 & \pm 0.5 & $912.0 \pm 117.0$ & $954.9 \pm 124.6$ & $162 . .1$ \\
\hline Jul & $29.4 \pm 0.2$ & $28.9 \pm 0.5$ & $32.4 \pm 1.0$ & 32.5 & \pm 1.3 & $1413.6 \pm 122.7$ & $1116.8 \pm 194.8$ & 55.5 \\
\hline Aug & $28.6 \pm 0.8$ & $28.2 \pm 0.6$ & $30.3 \pm 0.5$ & 30.8 & \pm 0.9 & $1173.3 \pm 94.9$ & $985.9 \pm 134.7$ & 80.9 \\
\hline Sep & $28.6 \pm 0.4$ & $28.7 \pm 0.3$ & $32.7 \pm 0.3$ & 33.2 & \pm 1.3 & $1147.4 \pm 82.4$ & $946.3 \pm 144.4$ & 25.2 \\
\hline Oct & $31.1 \pm 0.6$ & $30.4 \pm 0.1$ & $33.5 \pm 0.3$ & 34.0 & \pm 0.2 & $1501.6 \pm 109.8$ & $1463.8 \pm 271.8$ & 17.9 \\
\hline Nov & $31.1 \pm 0.7$ & $30.3 \pm 0.6$ & $33.9 \pm 1.4$ & 31.6 & \pm 0.6 & $1273.3 \pm 135.7$ & $1446.5 \pm 180.6$ & 241.3 \\
\hline Dec & $29.0 \pm 1.2$ & $28.8 \pm 0.2$ & $35.8 \pm 3.6$ & 31.4 & \pm 0.6 & $929.3 \pm 206.6$ & $879.4 \pm 110.7$ & 178.5 \\
\hline Jan & $31.5 \pm 0.7$ & $33.3 \pm 0.3$ & $33.2 \pm 0.8$ & 33.7 & \pm 0.9 & $1225.6 \pm 80.9$ & $1715.1 \pm 123.9$ & 0.5 \\
\hline Feb & $30.4 \pm 0.2$ & $30.9 \pm 1.2$ & $35.3 \pm 0.10$ & 35.6 & \pm 1.2 & $1458.1 \pm 101.1$ & $1368.8 \pm 230.1$ & 0.0 \\
\hline Mar & $29.7 \pm 0.9$ & $30.5 \pm 1.5$ & $34.30 \pm 2.5$ & 34.0 & \pm 2.1 & $1135.5 \pm 136.5$ & $1041.9 \pm 91.7$ & 83.2 \\
\hline
\end{tabular}

Table 2. Seasonal variation of chemical environmental variables measured at sampling stations at Maruhubi mangrove ecosystem (mean values \pm std error, nitrate $n=4$ )

\begin{tabular}{|c|c|c|c|c|c|c|c|}
\hline \multirow[b]{2}{*}{ Month } & \multicolumn{3}{|c|}{ Salinity (\%o) } & \multicolumn{2}{|c|}{$\mathrm{pH}$} & \multicolumn{2}{|c|}{ Nitrate concentation $\left(\mu \mathrm{g}\right.$-at $\left.\mathrm{NO}_{3}-\mathrm{N} / \mathrm{l}\right)$} \\
\hline & & St. I & St. II & St. I & St. II & St. I & St. II \\
\hline Apr & 35.0 & \pm 0.0 & $34.9 \pm 0.1$ & $6.7 \pm 0.1$ & $5.6 \pm 0.2$ & $0.7 \pm 0.2$ & $1.3 \pm 0.4$ \\
\hline May & 34.8 & \pm 0.1 & $35.1 \pm 0.1$ & $5.8 \pm 0.2$ & $5.9 \pm 0.1$ & $2.5 \pm 1.4$ & $2.8 \pm 0.0$ \\
\hline Jun & 35.5 & \pm 0.2 & $36.4 \pm 0.9$ & $7.1 \pm 0.1$ & $6.8 \pm 0.0$ & $0.6 \pm 0.5$ & $1.1 \pm 0.3$ \\
\hline Jul & 39.7 & \pm 0.1 & $41.4 \pm 0.9$ & $6.3 \pm 0.0$ & $6.0 \pm 0.2$ & $1.3 \pm 0.1$ & $2.1 \pm 0.2$ \\
\hline Aug & 37.6 & \pm 0.4 & $36.7 \pm 0.4$ & $6.2 \pm 0.1$ & $5.8 \pm 0.0$ & $1.3 \pm 0.3$ & $0.7 \pm 0.0$ \\
\hline Sep & 37.5 & \pm 0.6 & $37.8 \pm 0.4$ & $6.8 \pm 0.0$ & $4.9 \pm 0.1$ & $0.5 \pm 0.3$ & $0.4 \pm 0.2$ \\
\hline Oct & 37.1 & \pm 0.4 & $38.3 \pm 0.4$ & $5.7 \pm 0.3$ & $5.2 \pm 0.1$ & $0.4 \pm 0.1$ & $0.4 \pm 0.1$ \\
\hline Nov & 35.1 & \pm 0.1 & $34.0 \pm 0.2$ & $7.2 \pm 0.1$ & $5.7 \pm 0.0$ & $0.5 \pm 0.1$ & $1.2 \pm 0.5$ \\
\hline Dec & 34.3 & \pm 1.0 & $35.4 \pm 0.1$ & $6.6 \pm 0.0$ & $5.8 \pm 0.3$ & $1.8 \pm 0.0$ & $2.6 \pm 1.9$ \\
\hline Jan & 38.2 & \pm 1.8 & $45.9 \pm 1.4$ & $6.1 \pm 0.1$ & $5.3 \pm 0.4$ & $0.4 \pm 0.2$ & $0.6 \pm 0.5$ \\
\hline Feb & 37.6 & \pm 0.3 & $37.7 \pm 0.5$ & $7.3 \pm 0.0$ & $5.3 \pm 0.3$ & $0.8 \pm 0.1$ & $1.0 \pm 0.3$ \\
\hline Mar & 36.1 & \pm 0.4 & $36.5 \pm 0.5$ & $6.10 \pm 0.1$ & $4.8 \pm 0.2$ & $1.2 \pm 0.8$ & $1.5 \pm 0.1$ \\
\hline
\end{tabular}


Table 3. The statistical test results for combination of day and night $\mathrm{N}_{2}$ - fixation $\left(\mathrm{nmol} \mathrm{N}_{2} / \mathrm{hr}^{2} \mathrm{~m}^{2}\right)$ in relation to physical and chemical environmental variables. $r=$ correlation coefficient; $P \leq 0.05 ; S=$ significant, $N S=$ not significant

\begin{tabular}{|c|c|c|c|c|c|c|c|c|c|c|c|c|}
\hline \multirow[b]{3}{*}{$\mathrm{N}_{2}$ Fixation rate } & \multicolumn{12}{|c|}{ Variable $^{1}$} \\
\hline & \multicolumn{2}{|c|}{ AT } & \multicolumn{2}{|c|}{$\mathrm{ST}$} & \multicolumn{2}{|c|}{ LI } & \multicolumn{2}{|c|}{$\mathrm{pH}$} & \multicolumn{2}{|c|}{ Sal. } & \multicolumn{2}{|c|}{$\mathrm{NC}$} \\
\hline & I & II & I & II & I & II & I & II & I & II & I & II \\
\hline Nos. of points & 24 & 24 & 24 & 24 & 24 & 24 & 24 & 24 & 24 & 24 & 24 & 24 \\
\hline r-value & 0.2 & 0.0 & 0.4 & 0.0 & 0.3 & 0.1 & 0.7 & 0.1 & 0.1 & 0.1 & -0.2 & -0.2 \\
\hline p-value & 0.4 & 0.9 & 0.0 & 0.9 & 0.2 & 0.7 & 0.4 & 0.6 & 0.9 & 0.7 & 0.5 & 0.3 \\
\hline S or NS & NS & NS & $\mathrm{S}$ & NS & NS & NS & NS & NS & NS & NS & NS & NS \\
\hline
\end{tabular}

${ }^{1} \mathrm{AT}$, Air temperature in ${ }^{\circ} \mathrm{C}$; ST, sediment temperature in ${ }^{\circ} \mathrm{C}$; LI, light intensity in $\mu$ mole photons $\mathrm{m}^{2} / \mathrm{s}$; Sal., salinity in $\% o$; NC, nitrate concentration in $\mu \mathrm{g}$ atoms $\mathrm{NO}_{3}-\mathrm{N} / \mathrm{l}$.

The Spearman Rank Correlation test (Table 3) shows that generally there was no significant correlation between in situ nitrogen fixation and physical-chemical variables, except for sediment temperature, which showed a significant direct relationship with $\mathrm{N}_{2}$ fixation rate at Station I.

\section{DISCUSSION}

The cyanobacterial community composition results observed in this study can be compared with those of Lugomela et al. (2001) from a study performed at Mazizini also close to Zanzibar town. However, in this study more genera of filamentous nonheterocystous than heterocystous cyanobacteria are reported.

Our observation correlates well with the high $\mathrm{N}_{2}$-fixation rate observed during night times and low nitrogen fixation observed during the daytimes in both stations. Several studies (Rippka et al., 1979; Stal \& Krumbein, 1985; Bergman et al., 1997; Stal, 2000; Lundgren et al., 2001) show that unlike heterocystous cyanobacteria, which fix nitrogen during the day, most non-heterocystous cyanobacteria exercise a temporal separation of oxygenic photosynthesis and nitrogen fixation, with the former occurring during the day and the latter at night.

The non-heterocystous cyanobacteria in this study were more frequent and abundant compared to heterocystous cyanobacteria at both stations. There are no obvious explanations for this and more work is needed. A similar observation has been reported by Stal \& Krumbein (1985), who indicate that mat-forming heterocystous cyanobacterial species occur in very low frequencies due to their poorer adaptation to the environmental conditions in the mats, leading to less successful competition with other cyanobacteria. Our finding of no significant differences in the diversity of cyanobacterial groups between sandy and muddy sediments agrees with other studies showing that cyanobacteria are a diverse group of prokaryotes able to live under a wide range of environmental conditions (Fay, 1992; Stal et al., 1985; and Whitton \& Potts, 2000).

We found no statistically significant differences in nitrogen fixation between seasons at the stations and no significant relationship between in situ nitrogen fixation rates and physical-chemical variables (except sediment temperature, at Station I). Again, an explanation of these observations is impossible without further study. In the subtropical Balandra coastal lagoon at La Paz, Baja California Sur, Mexico in situ nitrogen fixation in summer was higher than in winter and temperature and light intensity were the primary environmental factors governing nitrogen fixation on mangrove pneumatophores (Toledo et al., 1995). This is similar to our observations on sandy sediments at Station I.

This study indicates that differences in nitrogen fixation rates between stations were only significant during the dry season. Differences in other limiting nutrients, such as phosphate, which was not investigated in this study, or of available combined nitrogen measured as nitrate, may play a role. Paerl (1996) showed that low nitrogen: 
phosphorous $(\mathrm{N}: \mathrm{P})$ ratios in ecosystems, often caused by excessive anthropogenic phosphate loading, enhance cyanobacterial growth. This stimulates higher nitrogen fixation rates in a given ecosystem. A report by Fredriksson (1996) shows that less combined nitrogen in an ecosystem increases the promotion of nitrogenase synthesis in cyanobacteria, and thus nitrogenase activity. In the present study, the observed higher nitrogen fixation rate at station I than that observed at station II during the dry season could be related to the low nitrate observed at station I and high nitrate observed at station II, although statistical analysis shows no significant correlation between nitrogen fixation and nitrate in this system.

The data presented here demonstrate considerably higher cyanobacterial diversity and nitrogen fixation rate in a mangrove ecosystem of Zanzibar Island than previously reported and indicates that, generally, seasonal changes do not influence the rate of nitrogen fixation. Additional studies are required to assess the influence of other factors, such as the effect of phosphate loading from the neighbouring Zanzibar town. In addition, further studies are needed to more accurately determine the primary productivity of the ecosystem.

Acknowledgements-Our sincere gratitude is expressed to Drs Julius Francis (former IMS Director), M. Mtorela (former IMS Associate and Acting Director), M. Björk, C. Lugomela, E. Söderbäck and A. Dubi (Director, IMS) for their helpful assistance. We are also grateful to the Institute of Marine Sciences, Zanzibar; Applied Microbiology Unit of University of Dar es Salaam; and Department of Botany, Stockholm University, for use of their facilities. We extend our thanks to the Swedish Agency for Research Cooperation (SIDA/SAREC) for the financial support which made this research possible. Finally, we are very grateful to the reviewers for their constructive comments, which significantly improved the manuscript.

\section{REFERENCES}

Alongi, D. M., Boto, K. G. \& Robertson, A. I. (1992) Nitrogen and phosphorus cycles. In: Robertson, A. I. \& Alongi, D. M. (eds). Tropical mangrove ecosystems. American Geographical Union, Washington, D. C. pp. 251-292.

Bergman, B., Gallon, J.R., Rai, A. N. and Stal, L. J. (1997). Nitrogen fixation by non-heterocystous cyanobacteria. FEMS Microbiology Reviews, pp.139-185.

Boto, K. G. \& Robertson, A. I. (1991) The relationship between nitrogen fixation and tidal exports of nitrogen in a tropical mangrove ecosystem. Estuarine, Coastal and Shelf Science 31: 531-540.

Burris, R. H. (1974) Methodology. In: Quespel, A. (ed.) The biology of nitrogen fixation. North Holland Publishing Company, Amsterdam. pp. 3-14.

Fay, P. (1992) Oxygen relations of nitrogen fixation in cyanobacteria. Microbiological Reviews 56: 340-373.

Fredriksson, C. (1996) Nitrogenase localization reveals cell differentiation in filamentous, nonheterocystous cyanobacteria. Doctoral thesis, Department of Botany, Stockholm University, pp. $1-12$.

Hicks, B. \& Silverster, W. (1985) Nitrogen fixation associated with New Zealand mangrove (Avicennia marina (Forsk.)) Vierh. Var. resinifera Forrsk. f. Bakl). Applied and Environmental Microbiology 49: 955-959.

Johnstone, R. \& Preston, M. (1993) Nutrient analysis in tropical marine waters. Practical guidance and safety notes for the performance of dissolved micronutrients analysis in seawater with particular reference to tropical waters. IOC Manuals and Guides 28. UNESCO.

Jonsson, K. (1988) Instructions for measurements of nitrogenase activity by the acetylene reduction method. Manuscript. Department of Forest Site Research, Swedish University of Agricultural Sciences.

Lugomela, C., Bergman, B. \& Waterbury, J. (2001) Cyanobacterial diversity and nitrogen fixation in coastal areas around Zanzibar, Tanzania. Algol. Stud. 103: 95-116.

Lundgren, P., Bauer K., Lugomela, C., Söderbäck, E. \& Bergman, B. (2001) Re-evaluation of the nitrogen fixation behaviour in the marine nonheterocystous cyanobacterium Lyngbya majuscula. In: Lugomela C. (PhD thesis). Cyanobacterial diversity and productivity in coastal areas of Zanzibar, Tanzania. Department of Botany, Stockholm University. pp. II:1-12.

Paerl, H.W. (1996) A comparison of cyanobacterial bloom dynamics in freshwater, estuarine and 
marine environments. Phycologia 35: 25-35.

Parsons, T. R., Maita, Y. \& Lalli, C. M. (1989) A manual of chemical and biological methods for sea water analysis. Pergamon Press. Oxford. pp. 14-17.

Potts, M. (1979) Nitrogen fixation (acetylene reduction) associated with communities of heterocystous and non-heterocystous blue-green algae in mangrove forests of Sinai. J. Gen. Microbiol. 39: 359-375.

Potts, M. (1984) Nitrogen fixation in mangrove forests. In: Por, F. D. \& Dor, I. (eds). Hydrobiology of the mangal. Dr. W. Junk Publishers, The Hague, The Netherlands. pp. 155-162.

Rippka, R., Deruelles, J., Waterbury, J. B., Herdman, M. \& Stanier, R. Y. (1979) Generic assignments, strain histories and properties of pure cultures of cyanobacteria. J. Gen. Microbiol. 111: 1-61.

Robertson, A. I. (1986) Leaf burying crabs: their influence on energy flow and export from mixed mangrove forest (Rhizophora spp.) in northeastern Australia. J. Exp. Mar. Biol. Ecol. 102: 237-248.

Semesi, A. K. (1991) Management plan of the mangrove ecosystem of mainland Tanzania. A document prepared for the Ministry of Tourism, Natural Resources and Environmental Forestry and Beekeeping Division Catchment Forestry Project, Dar es Salaam.

Semesi, A. K., Muruke, M. H. S. \& Mgaya, Y. D. (1999) Mangroves of Ruvu river and Kaole, Bagamoyo District. In: Howell, K. M. \& Semesi, A.K. (eds). Coastal resources of Bagamoyo District, Tanzania. Proceedings of a workshop on coastal resources of Bagamoyo, 18-19 December 1997, Bagamoyo. Faculty of Science, University of Dar es Salaam. pp. 17-25.

Shunula, J. P. \& Whittick A. (1996) The Mangroves of Zanzibar. Institute of Marine Sciences, University of Dar es Salaam. pp. i-iv, 1-65.
Stal, L. J. (1988) Nitrogen fixation in cyanobacterial mats. Methods in Enzymology 167: 174-178.

Stal, L. J. (2000) Cyanobacterial mats and stromatolites. In: Whitton, B. A. \& Potts, M. (eds), The ecology of cyanobacteria. Kluwer Academic Publishers, The Netherlands. pp. 61-120.

Stal, L.J. \& Krumbein, W.E. (1985) Isolation and characterisation of cyanobacteria from a marine microbial mat. Bot. Mar. 18: 118-125.

Toledo, G., Bashan, Y. \& Soeldner, A. (1995) Cyanobacteria and black mangroves in Northwestern Mexico: colonization, and diurnal and seasonal nitrogen fixation on aerial roots. Can. J. Microbiol. 41: 999-1011.

Villbrandt, M., Krumbein, W. E., Stal, L. J. \& Bergman, B. (1991) Diurnal and seasonal variations of nitrogen fixation and photosynthesis in cyanobacterial mats. Plant Soil 137: 13-16.

Whitton, B.A. and Potts, M. (2000) The introduction to the cyanobacteria. In: Whitton, B.A. and Potts, M. (eds). The ecology of cyanobacteria. Kluwer Academic Publishers, The Netherlands, pp. 1-11.

Woitchek, A. F., Ohowa, B., Kazungu, J. M., Rao, R. G., Goeyens, L. \& Dehairs, F. (1997) Nitrogen enrichment during decomposition of mangrove leaf litter in an East African coastal lagoon (Kenya): Relative importance of biological nitrogen fixation. J. Biogeochem. 39: 15-35.

Zuberer, D. A. \& Silver, W.S. (1974) Mangrove associated nitrogen fixation. In: Walsh, G., Snedaker, S. \& Teas, H. (eds). Proceedings of International Symposium on Biology and Management of Mangroves. Institute of Food and Agricultural Sciences, University of Florida, Gainesville, Fla. pp. 643-652.

Zuberer, D. A. \& Silver, W. S. (1978) Biological dinitrogen fixation (acetylene reduction) associated with Florida mangroves. Appl. Environ. Microbiol. 35: 567-575. 